\title{
PRESSURE DISTRIBUTION PATTERNS AND SHAPES OF FOOT UNDER LONG-TERM LOADS
}

\author{
Yunpeng TANG \\ Guizhou University of Commerce, Guiyang 550014, China, tang762267@163.com
}

PRESSURE DISTRIBUTION PATTERNS AND SHAPES OF FOOT UNDER LONG-TERM LOADS

\begin{abstract}
In this paper, we use instruments to scan the feet of athletes with no foot disease or previous injury from Beijing Sport University and ordinary college students from Tsinghua University and obtain the foot shapes and the changes therein of the subjects. Then we design and extract indices like foot length and foot width, perform statistic analysis of the foot shapes of young athletes under different loads, and obtain a group of data regarding the foot shape features of young athletes under different loads. This group of data can provide experimental operation experience and data support for the establishment of national young athlete foot shape index database. By analyzing the differences between the foot shape indices of young athletes under different loads, we find that different loads have some impacts on the foot shape changes. There are great differences between the foot shape indices of young athletes and ordinary college students in China, and of the young athletes in China, foot shape indices like foot length and width are likely to vary greatly due to different loads.
\end{abstract}

KEY WORDS: young athletes, foot shapes, different loads, characteristic index

\section{TIPARELE DE DISTRIBUȚIE A PRESIUNII ȘI FORMA PICIORULUI SUB SARCINI PE TERMEN LUNG}

REZUMAT. În această lucrare s-a obținut forma piciorului și modificările acestuia prin scanarea picioarelor unor sportivi din cadrul Universității de Sport din Beijing care nu au avut boli sau răni anterioare la nivelul picioarelor, și ale unor studenți obișnuiți ai Universității Tsinghua. Apoi s-au proiectat și extras indici precum lungimea și lățimea piciorului, s-a efectuat analiza statistică a formelor picioarelor sportivilor tineri sub sarcini diferite și s-a obtinut un grup de date privind caracteristicile formei piciorului sportivilor tineri sub diferite sarcini. Acest grup de date poate constitui o bază pentru experimente și un suport pentru crearea unei baze naționale a indicilor privind forma piciorului sportivilor. Analizând diferențele dintre indicii de formă a piciorului sportivilor tineri sub sarcini diferite, constatăm că diferite sarcini au impact asupra modificării formei piciorului. Există mari diferențe între indicii de formă a piciorului la sportivii tineri și studenții obișnuiți din China, iar în cazul tinerilor sportivi din China, indicii de formă a piciorului, cum ar fi lungimea și lățimea piciorului, pot varia foarte mult datorită sarcinilor diferite.

CUVINTE CHEIE: sportivi tineri, forma piciorului, sarcini diferite, indice caracteristic

\section{LES MODÈLES DE DISTRIBUTION DE PRESSION ET LES FORMES DU PIED SOUS DES PRESSIONS À LONG TERME}

RÉSUMÉ. Dans cet article, on utilise des instruments pour scanner les pieds des athlètes sans maladie du pied ou des blessures antérieures de l'Université sportive de Pékin et des étudiants universitaires ordinaires de l'Université de Tsinghua et on obtient les formes des pieds et leurs changements. Ensuite, on conçoit et on extrait des indices comme la longueur du pied et la largeur du pied, on fait une analyse statistique des formes des pieds des jeunes athlètes sous différentes pressions et on obtient un groupe de données concernant les caractéristiques de la forme du pied des jeunes athlètes sous différentes pressions. Ce groupe de données peut servir comme une base à des expériences et un soutien pour créer une base de données nationale pour les indices des formes du pied d'athlètes. En analysant les différences entre les formes du pied des jeunes athlètes sous différentes pressions, on a constaté que les différentes pressions ont eu un impact sur le changement de forme du pied. Il existe de grandes différences entre les indices des formes du pied chez les jeunes athlètes et les étudiants ordinaires en Chine ; chez les jeunes athlètes chinois, les indices telles que la longueur et la largeur du pied peuvent varier considérablement en raison de différentes pressions.

MOTS CLÉS: jeunes athlètes, formes des pieds, différentes pressions, indice caractéristique

\section{INTRODUCTION}

Foot shape varies greatly under the influences of factors like race, region, inheritance and life style [1]. For an individual, in human body support, balance and motion, affected by various factors like body weight, standing posture, exercise task and habit, exercise method and intensity and shoes, foot shape would also change accordingly [2]. And foot shape in turn affects the human body support, balance and movements.
As part of the human parameters of the main nationality in a country, foot shape features and the change patterns thereof have attracted the attention of scholars. After years of hard work, the public welfare project "Chinese foot shape database" in China has obtained numerous raw data. These data were collected through the field sampling measurement of people living in seven regions, namely North China, Northwest China, Southwest China, South China, Mid-South China, Northeast China and East China, which are very essential to the research on the foot shapes and

\footnotetext{
* Correspondence to: Yunpeng TANG, Guizhou University of Commerce, Guiyang 550014, China, tang762267@163.com
} 
patterns of populations in different areas [3]. This test mainly measured and recorded the foot length, width and girth and locations and lengths of the first metatarsophalangeal joint and the fifth metatarsophalangeal joint where there are obvious bone marks. The data obtained have become the foundation for research in medical and shoemaking fields. With the international development of sports and the increasingly fierce sports competition in the world, how to design hi-tech sports equipment to improve athletic performance has become an important research subject in countries all over the world. The first contactless laser 3D foot scanner in China jointly developed by "Do-win Professional Sports Shoe R\&D Center", Tsinghua University and Beijing Sport University integrate foot scanning, shoe last design and manufacturing and can customize shoes for high performance athletes [4]. A domestic research institute has studied the effects of gait on foot in a specific group of people under different loads and found that the greater the load is, the more likely the foot will get rubbed and the more serious the blisters will be on the foot. Further discussion can be carried out on this research result.

To sum up, how to study the patterns of foot shapes of athletes doing different sports by using the foot scanning technology and design personalized sports shoes according to their foot shape features will become important research contents and can be extended to new applications and research in clinical biomechanics [5], human ergonomics and sports biomechanics.

In this paper, we mainly study the foot shapes of young athletes from colleges in China and obtain a group of foot shape indices of young athletes to provide data support for the establishment of the athlete foot shape database [6], discuss the change patterns of foot shapes of young athletes in China under different static loads to provide theoretical basis for the research and development of athletic shoes and build an index system reflecting the foot shape features of athletes to explore how to set athletic shoe standards.

\section{Foot shape index experiment}

In this experiment, 31 female and 66 male athletes with no previous foot injuries from Beijing Sport University and 20 female and 40 male ordinary college students from Tsinghua University are selected. Athletes to be tested have an average age of 19.8 and have been trained for 4.2 years on average. Their training results have all reached national Level 2 . These athletes include 62 runners, 17 jumpers and 18 throwers. The ordinary college students have an average age of 20.7, and none of them has had any athletic training or foot injury before. Basic information on the experiment is listed in Tables 1 and 2.

The first contactless laser 3D foot scanner in China developed by Tsinghua University can perform no-dead-zone measurement of foot shapes [7]. The motion platform drives the laser under the drive of the servo motor [8], fast scans the foot and obtains the two-dimensional image of each foot section, and in this way obtains the three-dimensional point cloud data of the foot [9]. The equipment is shown in Figure 1. Through the processing and reconstruction of the scanning data, we extract the three-dimensional feature size of the foot and establish a 3D model for the foot. The scanning point cloud diagram is shown in Figure 2. The foot load measuring unit, which consists of multiple pressure sensors in the system, can measure and display the load size of the measured foot in real time [10].

Table 1: Information about the test

\begin{tabular}{ccc}
\hline & Young athletes & Ordinary college students \\
\hline Number of people & 97 & 60 \\
Age & $19.8 \pm 1.6$ & $20.7 \pm 1.6$ \\
Height $(\mathrm{cm})$ & $178.3 \pm 7.8$ & $170.0 \pm 7.3$ \\
Weight $(\mathrm{kg})$ & $71.0 \pm 7.9$ & $61.4 \pm 10.1$ \\
Shoe size(code) & $41 \pm 3$ & $40 \pm 2$ \\
\hline
\end{tabular}


Table 2: Basic information on the athletes

\begin{tabular}{ccccccccc}
\hline & $\begin{array}{c}\text { National Elite } \\
\text { Athletes }\end{array}$ & $\begin{array}{c}\text { National Level 1 } \\
\text { athletes }\end{array}$ & $\begin{array}{c}\text { National Level 2 } \\
\text { athletes }\end{array}$ & $\begin{array}{c}\text { 15 20 years } \\
\text { old }\end{array}$ & $\begin{array}{c}20 \sim 25 \\
\text { years old }\end{array}$ & Male & Female \\
\hline Runners & 4 & 19 & 39 & 18 & 44 & 42 & 20 \\
Jumpers & 0 & 10 & 7 & 7 & 10 & 13 & 4 \\
Throwers & 0 & 7 & 11 & 8 & 10 & 11 & 7 \\
Total & 4 & 36 & 57 & 33 & 64 & 66 & 31 \\
\hline
\end{tabular}

\section{ANALYSIS ON THE FOOT SHAPES OF ATHLETES UNDER DIFFERENT LOADS}

\section{Analysis on the Length Indices}

As shown in Table 3, the average foot length of athletes under different loads is $254.80 \pm 14.11 \mathrm{~mm}$, the average instep length is $149.62 \pm 15.44 \mathrm{~mm}$, the medial longitudinal arch length is $194.68 \pm 17.83 \mathrm{~mm}$, and the lateral

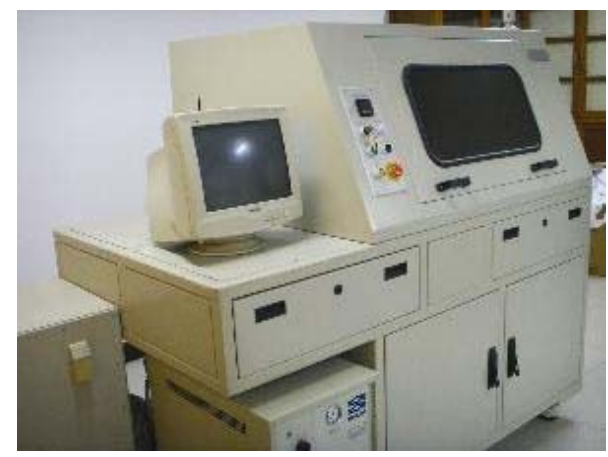

Figure 1. Contactless laser three-dimensional foot scanner

measured under $1 \mathrm{BW}+20 \mathrm{~kg}$;

- RW1 denotes: right foot measured under OBW; RW2 denotes: right foot measured under 1/2BW; RW3 denotes: right foot measured under 1BW; RW4 denotes: right foot measured under $1 \mathrm{BW}+20 \mathrm{~kg}$.

Eight groups of data including the foot length, instep length, medial longitudinal arch length and lateral longitudinal arch length of longitudinal arch length is $190.87 \pm 19.15 \mathrm{~mm}$.

Each subject is measured in four scenarios where the load is OBW, 1/2BW, 1BW and $1 \mathrm{BW} \pm 20 \mathrm{~kg}$ respectively, among them:

- LW1 denotes: left foot measured under OBW; LW2 denotes: left foot measured under $1 / 2 \mathrm{BW}$;

- LW3 denotes: left foot measured under 1BW; LW4 denotes: left foot

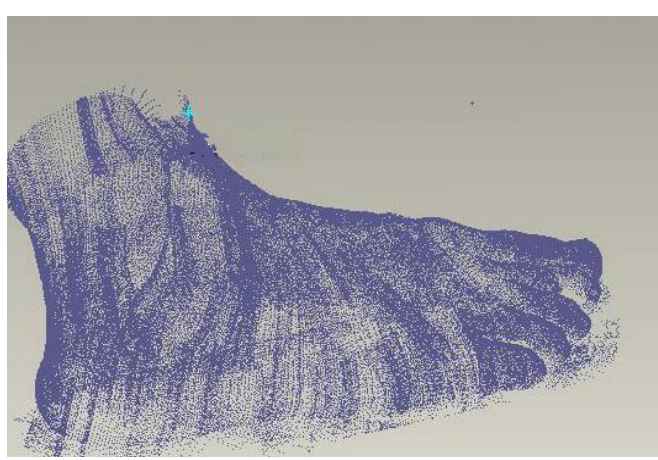

Figure 2. Scanned foot point cloud

the right and left feet are obtained. We perform analysis on the measured length indices and study the effects of different loads on the length indices [11].

As shown in Table 4 below, under different loads, the foot length indices of athletes all experience some changes. Under the same load, the data within one group have a greater degree of dispersion. The average values of the foot length indices of athletes all experience regular changes with the increasing load

Table 3: Basic information on length indices

\begin{tabular}{cccccc}
\hline & Data item & Average value & Standard deviation & Minimum value & $\begin{array}{c}\text { Maximum } \\
\text { value }\end{array}$ \\
\hline Foot length & 776 & 254.8 & 14.11 & 220 & 297 \\
Instep length & 776 & 149.62 & 15.44 & 101 & 198 \\
Medial longitudinal length & 776 & 194.68 & 17.83 & 144 & 244 \\
Lateral longitudinal length & 776 & 190.87 & 19.15 & 146 & 259 \\
\hline
\end{tabular}


and are all on the upward trend.

As shown in Table 5 below, under different loads, the foot length indices of athletes all experience some changes. Under the same load, the data within one group also have a greater degree of dispersion.

As shown in Table 6 above, under different loads, the medial longitudinal arch length of athletes changes. Under the same load, the data within one group have a greater degree of dispersion which have the same situation with Tables 4 and 5.
As shown in Figure 3, the average medial longitudinal arch lengths of athletes' right and left feet both experience regular changes with the increasing load and are all on the upward trend [12].

As shown in Figure 4, the average lateral longitudinal arch length of athletes' left feet reaches the maximum at a load of $\mathrm{OBW}$ and the minimum at a load of $1 / 2 \mathrm{BW}$, while for the right foot [13], the average lateral longitudinal arch length is the minimum at a load of OBW and the maximum at a load of $1 \mathrm{BW} \pm 20 \mathrm{~kg}$.

Table 4: Foot length indices under different loads

\begin{tabular}{lccccc}
\hline & Data item & Average value & Standard deviation & Minimum value & $\begin{array}{c}\text { Maximum } \\
\text { value }\end{array}$ \\
\hline LW1 & 96 & 253.42 & 13.777 & 220 & 290 \\
LW2 & 97 & 254.74 & 13.999 & 225 & 293 \\
LW3 & 97 & 255.6 & 14.441 & 227 & 297 \\
LW4 & 97 & 256.12 & 14.41 & 224 & 296 \\
RW1 & 96 & 253.5 & 14.016 & 226 & 289 \\
RW2 & 96 & 253.94 & 13.841 & 223 & 288 \\
RW3 & 96 & 255.27 & 14.319 & 227 & 294 \\
RW4 & 96 & 255.75 & 14.349 & 295 \\
\hline
\end{tabular}

Table 5: Instep length indices under different loads

\begin{tabular}{lccccc}
\hline & Data item & Average value & Standard deviation & Minimum value & $\begin{array}{c}\text { Maximum } \\
\text { value }\end{array}$ \\
\hline LW1 & 94 & 149.15 & 14.302 & 105 & 179 \\
LW2 & 95 & 150.05 & 15.94 & 114 & 182 \\
LW3 & 96 & 148.94 & 14.403 & 117 & 190 \\
LW4 & 96 & 148.39 & 15.433 & 114 & 186 \\
RW1 & 93 & 148.53 & 14.101 & 103 & 184 \\
RW2 & 94 & 149.21 & 16.864 & 111 & 193 \\
RW3 & 94 & 150.21 & 15.973 & 105 & 191 \\
RW4 & 94 & 149.31 & 16.713 & & 198 \\
\hline
\end{tabular}

Table 6: Medial Longitudinal arch length indices under different loads

\begin{tabular}{lccccc}
\hline & Data item & Average value & Standard deviation & Minimum value & $\begin{array}{c}\text { Maximum } \\
\text { value }\end{array}$ \\
\hline LW1 & 95 & 191.73 & 17.378 & 144 & 240 \\
LW2 & 96 & 193.97 & 16.375 & 144 & 239 \\
LW3 & 96 & 195.79 & 16.467 & 163 & 242 \\
LW4 & 96 & 196.07 & 17.585 & 164 & 243 \\
RW1 & 95 & 191.74 & 17.321 & 160 & 243 \\
RW2 & 94 & 193.85 & 19.156 & 151 & 243 \\
RW3 & 94 & 195.97 & 19.545 & 158 & 244 \\
RW4 & 95 & 198.33 & 18.245 & & 243 \\
\hline
\end{tabular}


In conclusion, a certain amount of load can cause significant changes in the medial longitudinal arch length and lateral longitudinal

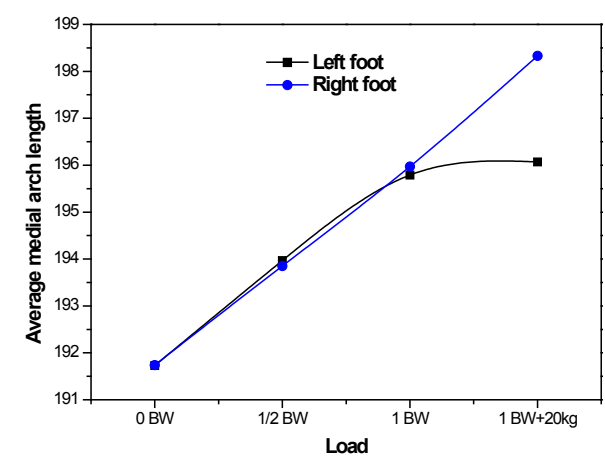

Figure 3. Average medial arch length under different loads

longitudinal arch length reflect the changes in the lateral longitudinal arch. The medial longitudinal arch length and lateral longitudinal arch length under a certain amount of load are significantly greater than those under no load, but when the load reaches a certain value, with the load increasing, the medial longitudinal arch length and lateral longitudinal arch length do not vary greatly [14].

\section{Distribution of Length Indices under Different Loads}

By major, the athletes are classified into three groups - runners, jumpers and throwers. By studying the indices of athletes of different majors under different loads, we analyze the effects of different majors on foot length indices, as shown in Table 7. We check and compare the foot length indices of the athletes of three majors under different loads, and find that for runners, the average foot length, medial longitudinal arch length and lateral longitudinal arch length are the smallest, and their average instep length is the largest; for jumpers, the average medial longitudinal arch length and lateral longitudinal arch length are the largest and the average foot length and instep length are medium; and for throwers, the average foot length is the largest, the average instep length is the smallest and the average medial longitudinal arch length and lateral longitudinal arch length are medium. arch length. Changes in the medial longitudinal arch length reflect the changes in the medial longitudinal arch while those in the lateral

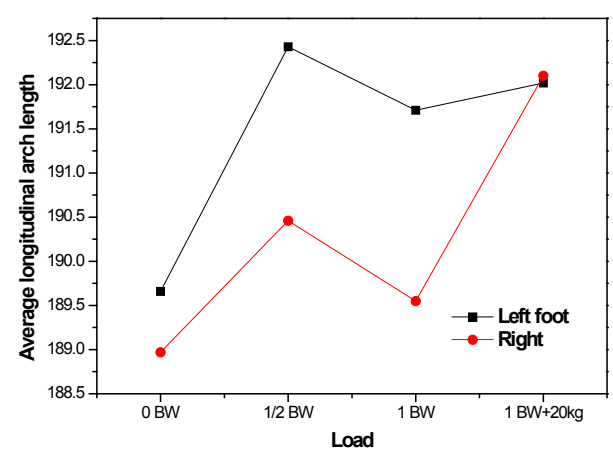

Figure 4. Average longitudinal arch length under different loads

We perform independent sample test on the length indices of runners, jumpers and throwers. According to the results, runners and jumpers have significant differences in the foot length, medial longitudinal arch length and lateral longitudinal arch length; runners and throwers vary greatly in foot length, instep length, medial longitudinal arch length and lateral longitudinal arch length; and jumpers and throwers vary greatly in foot length and medial longitudinal arch length. However, there is not much difference in the instep length and lateral longitudinal arch length.

\section{Distribution of Width Indices under Different Loads}

As shown in Table 8, the average foot width of athletes is $95.89 \pm 7.15 \mathrm{~mm}$, the minimum value is $75 \mathrm{~mm}$ and the maximum value is $124 \mathrm{~mm}$; the average heel width is $71.28 \pm 9.69 \mathrm{~mm}$, the minimum value is $58 \mathrm{~mm}$ and the maximum value is $114 \mathrm{~mm}$.

By measuring each subject in four scenarios where the load is $0 \mathrm{BW}, 1 / 2 \mathrm{BW}, 1 \mathrm{BW}$ and $1 \mathrm{BW} \pm 20 \mathrm{~kg}$ respectively, we obtain the data regarding the foot width and heel width and study the effects of different loads on the width indices.

As shown in Table 9, under different loads, the foot heel width indices of athletes all experience some changes. Under the same load, the data within one group have a smaller degree of dispersion. The average values of the 
foot width indices of athletes all experience regular changes with the increasing load and are all on the upward trend as can be seen in Figure 5. Under different loads, the heel widths of athletes all experience some changes. As shown in Figure 6, with the increasing load, the change patterns of heel widths of athletes are irregular. In the OBW case, the average heel width is the smallest; in the 1/2BW case, the average value is the largest; in the 1BW case, it is between the average values in the $1 / 2 \mathrm{BW}$ and $1 \mathrm{BW} \pm 20 \mathrm{~kg}$ cases.

Table 7: Basic information on the average values of length indices of different athletes

\begin{tabular}{|c|c|c|c|c|c|c|c|c|c|}
\hline \multicolumn{10}{|c|}{ 95\% mean difference confidence interval } \\
\hline & & $\begin{array}{l}\text { Sample } \\
\text { size }\end{array}$ & $\begin{array}{c}\text { Average } \\
\text { value }\end{array}$ & $\begin{array}{l}\text { Standard } \\
\text { deviation }\end{array}$ & $\begin{array}{l}\text { Standard } \\
\text { error }\end{array}$ & $\begin{array}{l}\text { Minimum } \\
\text { value }\end{array}$ & $\begin{array}{l}\text { Maximum } \\
\text { value }\end{array}$ & $\begin{array}{l}\text { Minimum } \\
\text { value }\end{array}$ & $\begin{array}{c}\text { Maximum } \\
\text { value }\end{array}$ \\
\hline \multirow{3}{*}{ Foot length } & Runners & 496 & 251.37 & 13.443 & 0.604 & 250.19 & 252.56 & 220 & 284 \\
\hline & Jumpers & 136 & 256.32 & 11.815 & 1.013 & 257.32 & 261.32 & 239 & 284 \\
\hline & Throwers & 139 & 262.58 & 14.278 & 1.211 & 260.19 & 264.98 & 228 & 297 \\
\hline \multirow{3}{*}{ Instep length } & Runners & 482 & 150.41 & 14.773 & 0.673 & 149.09 & 151.73 & 101 & 198 \\
\hline & Jumpers & 135 & 148.82 & 15.712 & 1.352 & 146.14 & 151.49 & 114 & 179 \\
\hline & Throwers & 139 & 145.49 & 16.870 & 1.431 & 142.66 & 148.32 & 103 & 190 \\
\hline \multirow{3}{*}{$\begin{array}{c}\text { Medial } \\
\text { longitudinal } \\
\text { arch length }\end{array}$} & Runners & 494 & 191.82 & 16.529 & 0.744 & 190.35 & 193.28 & 144 & 234 \\
\hline & Jumpers & 128 & 202.64 & 17.349 & 1.533 & 199.61 & 205.68 & 167 & 239 \\
\hline & Throwers & 139 & 197.54 & 20.038 & 1.700 & 194.18 & 200.90 & 159 & 244 \\
\hline \multirow{3}{*}{$\begin{array}{l}\text { Lateral } \\
\text { longitudinal } \\
\text { arch length }\end{array}$} & Runners & 493 & 188.31 & 18.930 & 0.853 & 186.63 & 189.98 & 146 & 249 \\
\hline & Jumpers & 136 & 196.35 & 17.134 & 1.469 & 193.45 & 199.26 & 169 & 259 \\
\hline & Throwers & 139 & 194.62 & 20.128 & 1.707 & 191.24 & 197.99 & 150 & 244 \\
\hline
\end{tabular}

Table 8: The basic unit of the width index of athletes Unit ( $\mathrm{mm}$ )

\begin{tabular}{cccccc}
\hline & Data item & Average & Standard deviation & Minimum value & Maximum \\
\hline Foot width & 771 & 95.89 & 7.15 & 75 & 124 \\
Heel Width & 770 & 71.28 & 9.69 & 58 & 114 \\
\hline
\end{tabular}

By major, the athletes are classified into three groups - runners, jumpers and throwers. By studying the indices of athletes of different majors under different loads, we analyze the effects of different majors on foot width indices, as shown in Figures 7 and 8.

Table 9: Length of the foot heel width under different loads

\begin{tabular}{|c|c|c|c|c|c|}
\hline & Data item & Average value & Standard deviation & Minimum value & Maximum \\
\hline LW1 & 96 & 70.60 & 8.951 & 48 & 110 \\
\hline LW2 & 97 & 73.2 & 9.630 & 56 & 110 \\
\hline LW3 & 97 & 71.88 & 9.766 & 53 & 110 \\
\hline LW4 & 97 & 72.08 & 10.377 & 48 & 110 \\
\hline RW1 & 96 & 69.50 & 9.074 & 53 & 96 \\
\hline RW2 & 96 & 71.63 & 8.763 & 58 & 95 \\
\hline RW3 & 96 & 70.53 & 9.769 & 53 & 96 \\
\hline RW4 & 95 & 70.78 & 10.932 & 48 & 114 \\
\hline
\end{tabular}


It can be seen that among the average foot width indices of athletes in three majors, the average foot width of runners is the smallest, followed by that of jumpers. The average foot width of throwers is the greatest, while the average heel width of jumpers is the smallest, that of the runners is medium and that of throwers is the largest. There are significant differences between runners and jumpers, runners and throwers and jumpers and throwers in terms of foot width and heel width.

Foot width is likely to change with different loads. Changes in this index mainly reflect the change pattern of the foot transverse arch under loads. Different loads have relatively small impact on the heel width. Changes in this index reflect the change pattern of the heel fat pad under loads. In the transition from OBW to

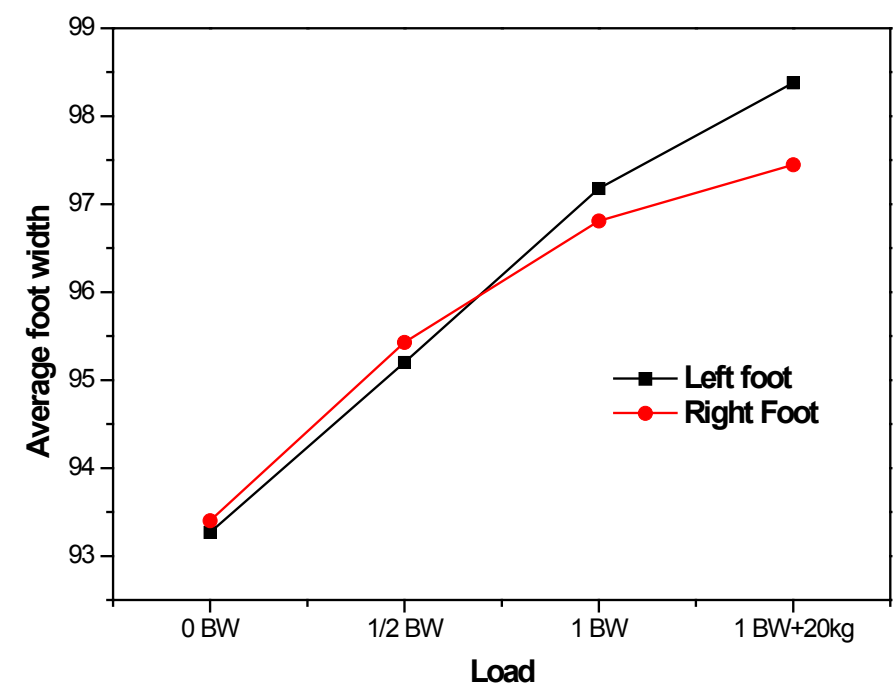

Figure 5. Average width of foot under different loads

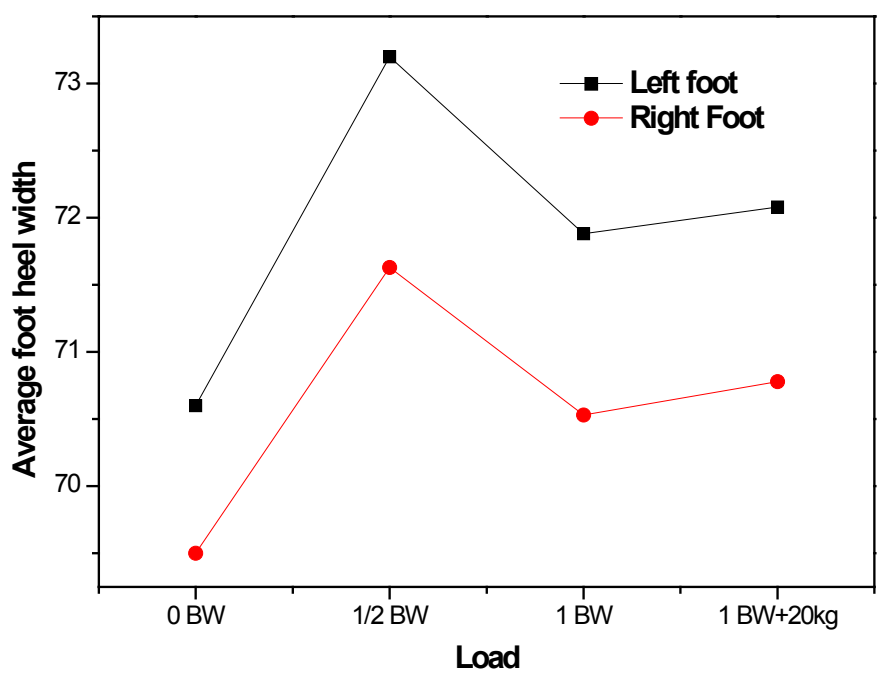

Figure 6. Average width of heel under different loads 
$1 / 2 \mathrm{BW}$, changes are obvious in the heel width, indicating that the heel fat pad changes greatly when it begins to bear load. Afterwards, with the load increasing, there is not much change in the heel width, indicating that additional load has no obvious impact on the heel width.

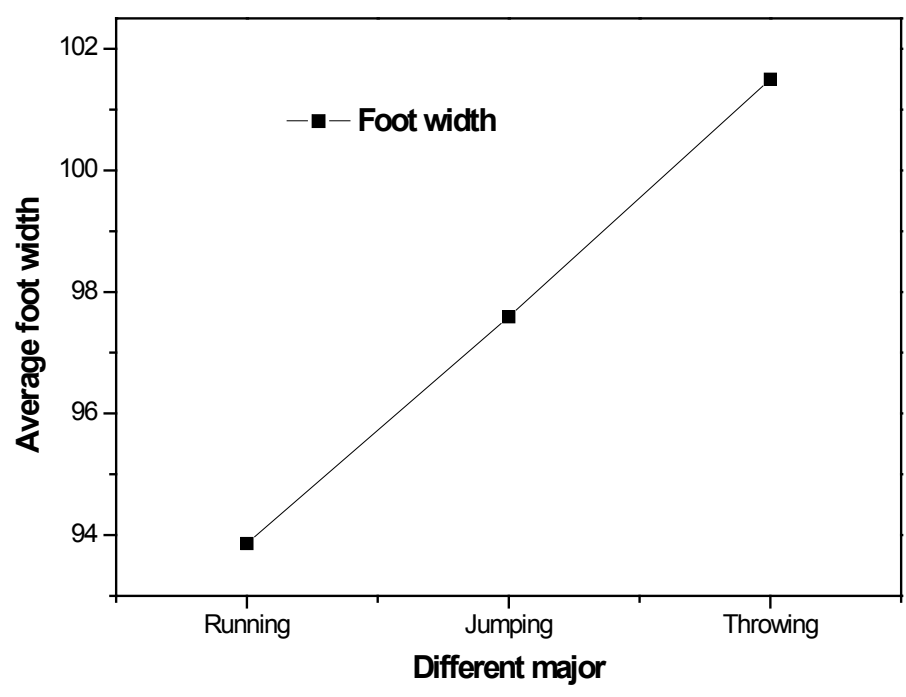

Figure 7. Average foot widths of athletes of different majors

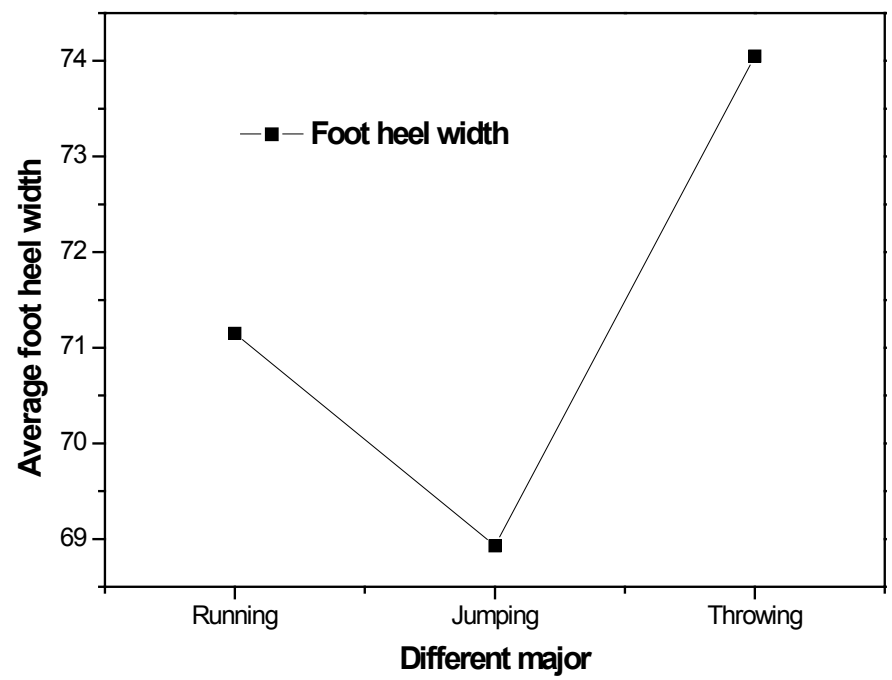

Figure 8. Average foot heel widths of athletes of different majors

Therefore, in shoemaking, the width of the metatarsophalangeal part should be more elastic than that of the heel to make the shoes more comfortable. In terms of foot width and heel width, there are significant differences between runners, jumpers and throwers. In future shoe last design, the great differences between the three types of athletes, especially in the foot width, which is an index reflecting the changes in the foot transverse arch, and the feature that throwers have the greatest foot width can all be taken into account. For example, the elastic range for the width of the metatarsophalangeal part can be increased as appropriate in the shoe last design for throwers in the future. 


\section{CONCLUSIONS}

In this paper, through the experimental design test, the young athlete's foot shape changes have been measured under different load parameters. The relevant data analysis shows that different loads have different impact on the foot shape changes. Besides, there are significant differences in the impact of different major sports on the foot shape indices. Specific conclusions are as follows:

(1) There are significant differences between runners, jumpers and throwers in terms of foot length and medial longitudinal arch length. In particular, the great differences between the three types of athletes in terms of the medial longitudinal arch length, which reflects the changes in the medial arch, can be taken into account in future shoe last design.

(2) Different loads have great impacts on the foot width. With the pressure increasing, the height of foot traverse arch is reduced, and the foot width gets larger, which further indicates that the foot traverse arch is quite sensitive to the load and can be easily increased with the increasing load. Therefore, in shoemaking, the width of the metatarsophalangeal part should be more elastic than that of the heel to make the shoes more comfortable.

The study of this paper has a positive effect on the biomechanics and clinical biomechanics of foot.

\section{REFERENCES}

1. Mihai, A., Dragomir, A., Driscu, M., Berijan, G., Comparative Study on the Assessment of Anthropometric Parameters Defining the 3D Shape of Diabetic and Arthritic Foot, Leather and Footwear Journal, 2009, 9, 1, 23-31.

2. Zhou, J., Zhang, W.W., Xu, B., Chen, W.Y, Effect of Arch Support on the Insole Pressure Distribution of Heel Heighted Shoes, Leather and Footwear Journal, 2012, 12, 4, 295-304.

3. Wang, J., Saito, H., Kimura, M., Mochimaru, M., Kanade, T., Human Foot Reconstruction from Multiple Camera Images with Foot Shape Database, IEICE Trans Inf Syst, 2008, E89-D, 5, 1732-1742, https://doi.org/10.1093/ietisy/ e89-d.5.1732.

4. Liu, G.Z., Wang, B.X., Shi, H., Luo, X.Z., Zhang, M.Z., Wang, R., Foot-Parameter-Extracting
Method Used in 3D Foot-Shape Measurement System, Chinese Journal of Biomedical Engineering, 2009.

5. Samson, W., Van, H.A., Sanchez, S., Chèze, L., Van, S.J.S., Feipel, V., Foot Roll-over Evaluation Based on 3D Dynamic Foot Scan, Gait Posture, 2014, 39, 1, 577, https://doi.org/10.1016/j. gaitpost.2013.09.014.

6. Ma, X., Luximon, A., 3D Foot Prediction Method for Low Cost Scanning, Int J Ind Ergon, 2014, 44, 6, 866-873, https://doi.org/10.1016/j. ergon.2014.08.006.

7. Kim, D.J., Bien, Z., Design of "Personalized" Classifier Using Soft Computing Techniques for "Personalized" Facial Expression Recognition, IEEE Trans Fuzzy Syst, 2008, 16, 4, 874-885, https://doi.org/10.1109/tfuzz.2008.924344.

8. Hodges, J.S., Peters, R.M., Non-Destructive Measurement of Foot/Notch on Etched Polysilicon Gates Using Spectroscopic Ellipsometry, IEEE International Symposium on Semiconductor Manufacturing, 2005, pp.406-409, IEEE Xplore. https://doi. org/10.1109/issm.2005.1513390.

9. Nurunnabi, A., West, G., Belton, D., Outlier Detection and Robust Normal-Curvature Estimation in Mobile Laser Scanning 3D Point Cloud Data, Pattern Recognit, 2015, 48, 4, 1404-1419, https://doi.org/10.1016/j. patcog.2014.10.014.

10. Harzhauser, M., Djuricic, A., Mandic, O., Zuschin, M., Dorninger, P., Nothegger, C. et al., Disentangling the History of Complex MultiPhased Shell Beds Based on the Analysis of 3D Point Cloud Data, Palaeogeogr Palaeoclimatol Palaeoecol, 2015, 437, 165-180, https://doi. org/10.1016/j.palaeo.2015.07.038.

11. Liu, G., Wang, B., Shi, H., Luo, X., Measurement System for 3-D Foot Shapes under Different Loads, International Technology and Innovation Conference 2006 (ITIC 2006), 246250, https://doi.org/10.1049/cp:20060763.

12. Kouchi, M., Analysis of Foot Shape Variation Based on the Medial Axis of Foot Outline, Ergonomics, 1995, 38, 9, 1911, https://doi. org/10.1080/00140139508925239.

13. Kouchi, M., Tsutsumi, E., Relation between the Medial Axis of the Foot Outline and 3-D Foot Shape, Ergonomics, 
1996, 39, 6, 853-861, https://doi. org/10.1080/00140139608964506.

14. Wunderlich, R.E., Griffin, N.L., Wickham, A.B., Gender Differences in Foot Function during Walking, Running and Turning: Implications for Overuse Injuries in Female Athletes, Clin Biomech, 2008, 23, 5, 705-706, https://doi. org/10.1016/j.clinbiomech.2008.03.050.
(C) 2017 by the author(s). Published by INCDTPICPI, Bucharest, RO. This is an open access article distributed under the terms and conditions of the Creative Commons Attribution license (http://creativecommons.org/licenses/by/4.0/). 